\title{
A clinical study of association of genital tuberculosis with infertility in a tertiary centre of Jharkhand, India
}

\author{
Samarina Kamal ${ }^{1 *}$, Vandita $\operatorname{Singh}^{2}$, Shashibala $\operatorname{Singh}^{3}$
}

\author{
${ }^{1}$ Department of Obstetrics and Gynecology, Alam Hospital and Research Centre Pvt. Ltd., Booty Raod Bariatu, Ranchi \\ Jharkhand, India \\ ${ }^{2}$ Department of Obstetrics and Gynecology, Sadar Hospital, Ranchi, Jharkhand, India \\ ${ }^{3}$ Department of Obstetrics and Gynecology, RIMS, Ranchi, Jharkhand, India
}

Received: 27 September 2019

Revised: 16 December 2019

Accepted: 19 December 2019

\section{*Correspondence:}

Dr. Samarina Kamal,

E-mail: drsamrinakamal@gmail.com

Copyright: () the author(s), publisher and licensee Medip Academy. This is an open-access article distributed under the terms of the Creative Commons Attribution Non-Commercial License, which permits unrestricted non-commercial use, distribution, and reproduction in any medium, provided the original work is properly cited.

\begin{abstract}
Background: The worldwide incidence of GTB is approximately 5-10\% in infertile women. It varies from as low as $0.69 \%$ in some developed countries to as high as $19 \%$ in India. It is diagnosed by culture of the tubercle bacillus from tissue sampled from the genital tract is the yardstick for diagnosis and remains the gold standard.

Methods: A prospective study was carried out between January 2012 and January 2015 on 100 women presenting with infertility.

Results: A total (27\%) women were diagnosed as genital tuberculosis by combination of hystero laparoscopic findings, histopathological and endometrial DNA-PCR technique confirmation. Of these (40.62\%) had secondary infertility and remaining $(59.38 \%)$ had primary infertility. $(15.62 \%)$ were previously diagnosed with pulmonary or extra pulmonary tuberculosis and had completed a full course of Anti-tubercular treatment as per WHO CAT 1 regime.

Conclusions: Therefore, in countries where TB is endemic, early and aggressive strategies should be pursued to diagnose and treat TB.
\end{abstract}

Keywords: Genital tuberculosis, Granuloma, Hysterolaparoscopy, Infertility, Paucibacillary, Polymerase chain reaction, Tubercles

\section{INTRODUCTION}

Tuberculosis remains a major health problem in many developing countries including India and, in these countries, genital tuberculosis is responsible for a significant proportion of women presenting with infertility. ${ }^{1}$ It is estimated that $5-10 \%$ of infertile women the world over have genital tuberculosis although this varies from less than $1 \%$ in the United States to nearly $18 \%$ in India. ${ }^{2}$ Female genital tuberculosis affects about $12 \%$ of patients having pulmonary tuberculosis. ${ }^{3}$ In $80-$ $90 \%$ of cases, FGTB affects young women of $18-38$ years of age and is an important cause of infertility. ${ }^{4}$ The fallopian tubes $(92-100 \%)$ are the most commonly affected genital organs, followed by endometrium $(50 \%)$, 4 ovary (10-30\%), cervix (5\%) and vulva and vagina (< $1 \%)$. According to Novak's, the tubes are already affected when the diagnosis of tubercular endometritis is made. ${ }^{5}$ The characteristic feature is the presence of yellowishgrey tubercles on the peritoneal surface of the tubes and mesosalpinx with fimbrial end of tube remaining open in half the cases. ${ }^{6}$ Genital tuberculosis is a disease of silent nature. Infertility is the most common presentation amongst women in the childbearing age 
group (43-74\%). Other clinical presentations include oligomenorrhoea $(54 \%)$, amenorrhea $(14 \%)$, menorrhagia (19\%), abdominal pain $(42.5 \%)$, dyspareunia $(5-12 \%)$ and dysmenorrhea $(12-30 \%){ }^{7}$ Diagnosis of FGTB is often limited to clinical suspicion. A pelvic USG is of help in presence of TO masses. Definitive diagnosis of FGTB is possible only by the isolation of mycobacterium tuberculosis bacteria from genital tract or histological demonstration of granuloma. The material taken for culture or biopsy is the endometrium and menstrual discharge. ${ }^{8}$ The best time for collecting endometrial sample is several days before expected menses when tubercles reach maximum growth. The polymerase chain reaction (PCR) is a rapid method for detection and quantification of few DNA copies with high sensitivity and specificity, the results being available in 1 day. PCR may be positive with only $1-10$ organisms $/ \mathrm{ml} .{ }^{9}$ On hysteroscopy, no classical features are described but intrauterine adhesions, scarring or narrowing of cavity may be found. Diagnosing genital tuberculosis is a challenge because of varied clinical presentations, diverse results on imaging and laparoscopy, and a mixed bag of bacteriological and serological tests. ${ }^{10}$ Diagnosis by culture of the tubercle bacillus from tissue sampled from the genital tract is the yardstick for diagnosis and remains the gold standard. However, in spite of inoculation into multiple media only $5-6 \%$ of samples yield microbiological proof of mycobacteria by culture, the reason being the paucibacillary nature of the organism, bacteriologically mute genital lesions, presence of bacteriostatic substance in endometrium and cyclic shedding of endometrium which leads to inadequate granuloma formation in each cycle. Short-course chemotherapy (DOTS) for 6-9 months has been found to be effective for medical treatment of FGTB. ${ }^{11,12}$ The chances of pregnancy in females suffering from genital TB have so far been poor $(5 \%)$ even after completion of treatment.

\section{METHODS}

A prospective study was carried out between January 2012 and January 2015 on 100 women presenting with infertility.

Women of reproductive age group (20-40 years) presenting with primary or secondary infertility of more than one-year duration and an active married life were included in the study.

Detailed history was taken, clinical examination, hematological investigations, pelvic ultrasound, semen analysis, hormonal assays were done.

All 100 women were posted for diagnostic hysterolaparoscopy after informed consent.

Endometrial curettage was done during the procedure and the sample was sent for histopathology and the specialized laboratory for TB-PCR.
Laparoscopic findings like tubal blocks, peritubal adhesions, hydrosalpinges, tubo-ovarian masses and tubercles were noted.

Hysteroscopic findings like cervical stenosis, narrow uterine cavity, endometrial bands and synechia, blocked tubal ostia, scanty endometrium and tubercles in the endometrium were documented.

In one woman of abdominal tuberculosis, introduction of trocar and cannula was difficult from supra and infra umbilical site, hence trocar and cannula was introduced through Palmer`s point.

In another woman, we were unable to negotiate the cervical os, due to cervical stenosis. Hence hysteroscopy was abandoned. This patient showed extensive signs of tuberculosis on laparoscopy.

\section{RESULTS}

Out of 100 patients enrolled in our study 71 had never been pregnant before. One patient was not sure whether she had miscarriage or delayed periods. (Pregnancy was not documented) so was put under primary infertility group (Table 1).

Table 1: Distribution of cases according to type of infertility.

\begin{tabular}{|lll|}
\hline Total no. of cases & $\begin{array}{l}\text { Primary } \\
\text { infertility }\end{array}$ & $\begin{array}{l}\text { Secondary } \\
\text { infertility }\end{array}$ \\
\hline 100 & 71 & 29 \\
\hline
\end{tabular}

Table 2: Distribution of cases in relation to socioeconomic status $(\mathbf{N}=\mathbf{1 0 0})$.

\begin{tabular}{|lllll|}
\hline $\begin{array}{l}\text { Types of } \\
\text { infertility }\end{array}$ & $\begin{array}{l}\text { No. of } \\
\text { cases }\end{array}$ & Low & $\begin{array}{l}\text { Low } \\
\text { middle }\end{array}$ & $\begin{array}{l}\text { High } \\
\text { middle }\end{array}$ \\
\hline Primary & 71 & $47(66.19)$ & $17(23.9)$ & $7(9.8)$ \\
\hline Secondary & 29 & $19(65.51)$ & $5(17.2)$ & $5(17.2)$ \\
\hline Total & $\mathbf{1 0 0}$ & $\mathbf{6 6}$ & $\mathbf{2 2}$ & $\mathbf{1 2}$ \\
\hline
\end{tabular}

Most patients belonged to low socioeconomic status both in primary and secondary infertility groups. 88 patients out of 100 came from low income group showing that tuberculosis is a disease of unpriviledged (Table 2).

Table 3: Age distribution of cases.

\begin{tabular}{|lllll|}
\hline $\begin{array}{l}\text { Types of } \\
\text { infertility }\end{array}$ & $\begin{array}{l}\text { No. of } \\
\text { cases }\end{array}$ & $\begin{array}{l}<20 \\
\text { years }\end{array}$ & $\begin{array}{l}\mathbf{2 1 - 3 0} \\
\text { years }\end{array}$ & $\begin{array}{l}\mathbf{3 1 - 4 0} \\
\text { years }\end{array}$ \\
\hline $\begin{array}{l}\text { Primary } \\
\text { infertility }\end{array}$ & 71 & $9(12.6)$ & $41(57.7)$ & $21(29.5)$ \\
\hline $\begin{array}{l}\text { Secondary } \\
\text { infertility }\end{array}$ & 29 & $2(6.8)$ & $10(34.4)$ & $17(58.6)$ \\
\hline Total & $\mathbf{1 0 0}$ & $\mathbf{1 1}$ & $\mathbf{5 1}$ & $\mathbf{3 9}$ \\
\hline
\end{tabular}


Table 3 shows the maximum number of cases were in the age group of 21-30 years i.e. 51 out of 100 .

Table 4: Distribution of cases in relation to duration of infertility.

\begin{tabular}{|llllll|}
\hline Types of infertility & No. of cases & $\mathbf{2 - 3}$ years & $\mathbf{4 - 5}$ years & $\mathbf{6 - 1 0}$ years & $>11$ years \\
\hline Primary infertility & 71 & $5(7.04)$ & $26(36.6)$ & $40(56.3)$ & 0 \\
\hline Secondary infertility & 29 & $2(6.8)$ & $7(24.1)$ & $18(62.06)$ & $2(6.8)$ \\
\hline Total & $\mathbf{1 0 0}$ & $\mathbf{7}$ & $\mathbf{3 3}$ & $\mathbf{5 8}$ & $\mathbf{2}$ \\
\hline
\end{tabular}

Table 4 shows that the majority of cases with infertility both primary and secondary are in the group 6-10 years of infertility (58\%) followed by $4-5$ years $(33 \%)$. This shows that among infertile women, TB comes as a late diagnosis.

Table 5: Distribution of cases in relation to parity in secondary infertility.

\begin{tabular}{|lll|}
\hline Parity & No. of case & History of abortion \\
\hline PO & $10(34.4)$ & $10(34.4)$ \\
\hline P1 & $14(48.2)$ & $7(24.1)$ \\
\hline P2 & $5(17.2)$ & $1(3.4)$ \\
\hline Total & $\mathbf{2 9}$ & $\mathbf{1 8}$ \\
\hline
\end{tabular}

Table 6: Distribution of cases in relation abnormal clinical finding.

\begin{tabular}{|ll|ll|}
\hline & $\begin{array}{l}\text { Abnormal clinical } \\
\text { finding }\end{array}$ & $\begin{array}{l}\text { No. of } \\
\text { cases }\end{array}$ & $\%$ \\
\hline $\begin{array}{l}\text { On general } \\
\text { examination }\end{array}$ & $\begin{array}{l}\text { Very poor general } \\
\text { health (weight }<38 \mathrm{~kg})\end{array}$ & 15 & 15 \\
\hline \multirow{2}{*}{$\begin{array}{l}\text { Per } \\
\text { abdominal } \\
\text { examination }\end{array}$} & Abdominal doughy & 8 & 8 \\
\cline { 2 - 4 } & $\begin{array}{l}\text { abdominal lump } \\
\text { distension (ascities) }\end{array}$ & 4 & 4 \\
\hline $\begin{array}{l}\text { Per } \\
\text { speculum } \\
\text { examination }\end{array}$ & Cervical lesion & 2 & 2 \\
\cline { 2 - 4 } & Vaginal discharge & 8 & 8 \\
\hline \multirow{2}{*}{$\begin{array}{l}\text { Per vaginal } \\
\text { discharge }\end{array}$} & $\begin{array}{l}\text { Uterine mobility } \\
\text { restricted }\end{array}$ & 14 & 14 \\
\cline { 2 - 4 } & Fornices tender & 10 & 10 \\
\hline
\end{tabular}

Table 5 shows that maximum number of secondary infertility cases belong to P1 (parity 1) 14/29 (48.2\%), followed by P0 (history of abortion) $34.4 \%$ cases. This shows that tuberculosis affects women in early part of their reproductive career. Table 6 showed the most common sign was restricted mobility of uterus and full blown tubo-ovarian mass was seen only in $4 \%$ cases. Most cases had non-specific clinical symptoms making it a diagnostic enigma.

Table 7 shows that the history of pulmonary tuberculosis was positive in only 4 cases. In most cases tuberculosis came as a surprise diagnosis during infertility work up.

Table 7: Association of infertility with previous history of pulmonary tuberculosis.

\begin{tabular}{|llll|}
\hline Types of infertility & $\begin{array}{l}\text { No. of } \\
\text { cases }\end{array}$ & Negative & Positive \\
\hline Primary infertility & 71 & $67(94.3)$ & $4(5.63)$ \\
\hline Secondary infertility & 29 & $29(100)$ & 0 \\
\hline
\end{tabular}

Table 8: Distribution of cases in relation to abnormal menstrual pattern.

\begin{tabular}{|llll|}
\hline $\begin{array}{l}\text { Types of } \\
\text { infertility }\end{array}$ & $\begin{array}{l}\text { No. of } \\
\text { cases }\end{array}$ & $\begin{array}{l}\text { Normal } \\
\text { menses }\end{array}$ & $\begin{array}{l}\text { Abnormal } \\
\text { menses }\end{array}$ \\
\hline $\begin{array}{l}\text { Primary } \\
\text { infertility }\end{array}$ & 71 & $40(56.3)$ & $31(43.33)$ \\
\hline $\begin{array}{l}\text { Secondary } \\
\text { infertility }\end{array}$ & 29 & $12(41.66)$ & $17(58.33)$ \\
\hline Total & $\mathbf{1 0 0}$ & $\mathbf{5 2}$ & $\mathbf{4 8}$ \\
\hline
\end{tabular}

Table 8 showed that there was no positive correlation with menstrual abnormality.

Table 9 showed that most common symptom was nonspecific menstrual abnormality.

Table 9: Distribution of cases in relation of different menstrual disorder.

\begin{tabular}{|lllllllll|}
$\begin{array}{l}\text { Types of } \\
\text { infertility }\end{array}$ & $\begin{array}{l}\text { Abnormal } \\
\text { menses }\end{array}$ & $\begin{array}{l}\text { Pelvic } \\
\text { pain }\end{array}$ & $\begin{array}{l}\text { Secondary } \\
\text { amenorrhoa }\end{array}$ & Dysmenorrhoa & $\begin{array}{l}\text { Oligom } \\
\text { enorrhoa }\end{array}$ & Menorrhagia & Polymenorrhoea & $\begin{array}{l}\text { Dysoligo } \\
\text { menorrhoa }\end{array}$ \\
\hline $\begin{array}{l}\text { Primary } \\
\text { infertility }\end{array}$ & $31(43.33)$ & $5(7.04)$ & $6(7.04)$ & $2(2.8)$ & $7(9.8)$ & $2(2.8)$ & $2(2.8)$ & $7(10)$ \\
\hline $\begin{array}{l}\text { Secondary } \\
\text { infertility }\end{array}$ & $17(58.33)$ & $5(17.2)$ & $3(10.3)$ & $3(10.3)$ & $4(17.2)$ & 0 & 0 & $2(6.8)$ \\
\hline Total & $\mathbf{4 8}$ & $\mathbf{1 0}$ & $\mathbf{9}$ & $\mathbf{5}$ & $\mathbf{1 1}$ & $\mathbf{2}$ & $\mathbf{2}$ & $\mathbf{9}$ \\
\hline
\end{tabular}


Table 10: Result of routine investigations.

\begin{tabular}{|llllll|}
\hline Types of infertility & Raised lymphocytes & Raised ESR & $\begin{array}{l}\text { Mantoux } \\
\text { positive }\end{array}$ & $\begin{array}{l}\text { Collection in } \\
\text { pouch of douglass }\end{array}$ & $\begin{array}{l}\text { Tubo ovaraion } \\
\text { mass }\end{array}$ \\
\hline Primary infertility & $38(53.5)$ & $32(45.07)$ & $31(43.6)$ & $30(42.2)$ & $1(1.4)$ \\
\hline Secondary infertility & $10(34 \%)$ & $12(41.3)$ & $7(24.1)$ & $10(34.4)$ & $3(44.8)$ \\
\hline
\end{tabular}

Table 10 showed that lymphocytosis, raised ESR, Positive montoux and USG finding of fluid in pouch of douglas were associated with pelvic tuberculoses. Individually, they may be non-specific but into they raise a definite suspicion of pelvic tuberculosis.

Table 11 showed that acid fast bacilli was seen on microscopy only in $29.8 \%$ cases. But in absence of AFB, tuberculosis cannot be ruled out, resorting to other diagnostic tools.

Table 11: Result of smear microscopy for acid fast bacilli $(\mathrm{n}=\mathbf{1 0 0})$.

\begin{tabular}{|lll|}
\hline Types of infertility & No. of cases & $\begin{array}{l}\text { Positive } \\
\text { result }(\%)\end{array}$ \\
\hline Primary infertility & 71 & $9(12.6)$ \\
\hline Secondary infertility & 29 & $5(17.2)$ \\
\hline Total & $\mathbf{1 0 0}$ & $\mathbf{1 4}$ \\
\hline
\end{tabular}

Table 12: Result of KOCH'S culture of endometrial tissue on $\mathbf{L} \mathbf{J}$ Media.

\begin{tabular}{|lll|}
\hline Types of infertility & No. of cases & $\begin{array}{l}\text { Positive } \\
\text { culture }\end{array}$ \\
\hline Primary infertility & 71 & 14 \\
\hline Secondary infertility & 29 & 5 \\
\hline Total & $\mathbf{1 0 0}$ & $\mathbf{1 9}$ \\
\hline
\end{tabular}

Table 12 showed that positive culture was seen only in 19 cases. But if positive, it clinches the diagnosis. The disadvantage being the long time period required for the test.

Table 13 showed that positive result on HPE of endometrial tissue was seen only in $50.83 \%$ cases.

Table 13: Result of H P E of endometrial tissue.

\begin{tabular}{|lll|}
\hline Types of infertility & No. of cases & $\begin{array}{l}\text { Positive } \\
\text { results }\end{array}$ \\
\hline Primary infertility & 71 & $9(26.7 \%)$ \\
\hline Secondary infertility & 29 & $7(24.13 \%)$ \\
\hline Total & $\mathbf{1 0 0}$ & $\mathbf{2 6}$ \\
\hline
\end{tabular}

Table 14 showed that most patients were diagnosed by positive hystero-laparoscopy. It also allows corrective surgery in the same sitting making it the gold standard diagnostic tool.
Table 14: Mode of diagnosis of genital tuberculosis $(\mathbf{N}=32)$.

\begin{tabular}{|ll|}
\hline Mode of diagnosis & No. of patients diagnosed GTB \\
\hline Hystero-laparoscopy & $(94 \%)$ \\
\hline TB-PCR & $(58 \%)$ \\
\hline HPR & $(10 \%)$ \\
\hline
\end{tabular}

Table 15: Laparoscopic finding $(\mathbf{N}=100)$.

\begin{tabular}{|ll|}
\hline Finding & Number \\
\hline PCOS (polycystic ovarian syndrome) & $(23 \%)$ \\
\hline Peritubal adhesions & $(18 \%)$ \\
\hline Tubal block & $(10 \%)$ \\
\hline Beaded tube & $(7 \%)$ \\
\hline Cornual block & $(9 \%)$ \\
\hline Normal & $(29 \%)$ \\
\hline Hydrosalpinx & $(8 \%)$ \\
\hline Clubbed fimbria & $(8 \%)$ \\
\hline Frozen pelvis & $(7 \%)$ \\
\hline Endometriosis & $(19 \%)$ \\
\hline Others (fibroid, anomalous uterus) & $(10 \%)$ \\
\hline
\end{tabular}

Table 15 showed that $29 \%$ cases showed normal anatomy while $71 \%$ cases had some positive laparoscopic findings. This makes it a very good diagnostic method allowing fertility enhancing surgery at the same sitting.

Table 16: Findings on hysteroscopy $(\mathbf{N}=100)$.

\begin{tabular}{|ll|}
\hline Finding & Number \\
\hline Normal & $(55 \%)$ \\
\hline Synechia/fibrosed endometrium & $(18 \%)$ \\
\hline Other (fibroid, polyp, anomaly) & $(12 \%)$ \\
\hline Narrow cavity & $(8 \%)$ \\
\hline Scarring of cornu & $(4 \%)$ \\
\hline Cervical stenosis & $(1 \%)$ \\
\hline
\end{tabular}

Table 17: Outcome of study $(\mathrm{N}=9)$.

\begin{tabular}{|ll|}
\hline Outcome & $\begin{array}{l}\text { No. of women /total with } \\
\text { GTB }\end{array}$ \\
\hline Delivered & $(16 \%)$ \\
\hline Spontaneous abortion & $(6 \%)$ \\
\hline Ectopic & $(3 \%)$ \\
\hline Biochemical pregnancy & $(3 \%)$ \\
\hline
\end{tabular}


Table 16 showed normal hysteroscopic finding in 55\% cases. Most common (18\%) abnormality was uterine synechia. Table 17 showed that only $16 \%$ pregnancies resulted in take home babies.
Table 18 showed the comparison of our study with different studies as regards different diagnostic methods and prognosis.

Table 18: Different studies of genital tuberculosis.

\begin{tabular}{|llllll|l|}
\hline Studies & Present study & Puri et al & Kulshrestha et al & Baxi et al & Sharma et al & Bapna et al \\
\hline GTB & $27 \%$ & - & $60 \%$ & - & - & $16.4 \%$ \\
\hline TB PCR & $58 \%$ & $46.67 \%$ & $41.3 \%$ & $32 \%$ & $64.7 \%$ & - \\
\hline HL scopy & $93 \%$ & - & $9.1 \% \pm 37.4 \%$ & $42.52 \%$ & $47 \%$ & - \\
\hline Conception rate & $28 \%$ & $19.35 \%$ & $22.9 \%$ & - & - & $19.1 \%$ \\
\hline
\end{tabular}

In present study, a total of 100 women had undergone diagnostic hystero-laparoscopy, for infertility. The mean duration of infertility was 6-10 years. Most women were between 22 years to 39 years of age.

A total (27\%) women were diagnosed as genital tuberculosis by combination of hystero laparoscopic findings, histopathological and endometrial DNA-PCR technique confirmation. Of these $(40.62 \%)$ had secondary infertility and remaining $(59.38 \%)$ had primary infertility. (15.62\%) were previously diagnosed with pulmonary or extra pulmonary tuberculosis and had completed a full course of Anti-tubercular treatment as per WHO CAT 1 regime.

Of these, (94\%) had clearly seen findings pointing towards TB on hystero- laparoscopy, such as beaded tubes, peritubal adhesions, frozen pelvis, blocked tubes, tubercles on the pelvic organs.

Hysteroscopic findings mainly suggestive of tuberculosis include fibrosed endometrium, narrow cavity and cornual scarring. However, only in $(58 \%)$ patients TB-PCR was positive.

In $(10 \%)$ of the diagnosed women, endometrial histopathology revealed presence of granulomatous lesions. Culture of mycobacterium is the gold standard but has a limited yield. A total 32 women after diagnosis were given standard 4 drugs anti-tubercular treatment (ATT) for 6 months. In 10 women, we added steroids, for the initial 2 months, to decrease the occurrence of fibrosis. One woman was diagnosed with lumbosacral Koch`s hence anti tubercular drugs were given for 9 months. Out of the, 32 diagnosed women of genital tuberculosis, 9 women conceived with treatment (28\%).

\section{DISCUSSION}

Mean age in our study was 26.3 years which was comparable to studies of Rozati R et al and Gupta N et al. ${ }^{13,14}$ Study by Puri et al, gives $46.67 \%$ positive TB PCR results. ${ }^{8,20}$ In a study by Kulshrestha et al genital tuberculosis was diagnosed in $60.2 \%$ infertility women. ${ }^{15}$
In 1976, Schaefer reviewed 7000 cases of genital tuberculosis from the literature and stated that 155 patients had full term pregnancies $(2.2 \%), 67$ had abortions (0.9\%), and 125 (1.8\%) had ectopic pregnancies. ${ }^{16}$ A study by Bapna et al, documented $12.5 \%$ women of GTB having positive histopathological reports. ${ }^{17}$ In the present study, we diagnosed $10 \%$ of GTB cases on endometrial HPR.

Sin SY et al studied that if patients are adequately treated before tubes are irreversibly damaged, chance of successful pregnancy is reasonably good with $20 \%$ pregnancy rate reported. ${ }^{18}$ The conception rate was $19.2 \%$ while the live birth rate was only $7.2 \%$ in a study by Tripathy SN. ${ }^{19}$ The presenting symptoms are related to menstrual irregularities and infertility. Early diagnosis and treatment will improve fertility outcome.

In the present study, $58 \%$ positive TB-PCR results were comparable with a study in New Delhi, which documented $56 \%$ of infertile patients as TB-PCR positive. Laparoscopy indicated definitive GTB in $9.1 \%$ and probable GTB in $37.4 \%$, and TB-PCR was positive in $41.3 \%$ of women. In the present study, we diagnosed $10 \%$ of GTB cases on endometrial HPR. In this study, conception rate is $28 \%$ after starting AKT.

\section{CONCLUSION}

TB being endemic in developing countries like India, it is often a leading cause of infertility. Hystero-laparoscopy also diagnoses concomitant causes of infertility like, endometriosis, PCOS and uterine anomalies. TB-PCR is a reliable diagnostic tool. ATT started early, may give a significant advantage in improving the chances of conception. Therefore, in countries where TB is endemic, early and aggressive strategies should be pursued to diagnose and treat $\mathrm{TB}$.

Funding: No funding sources

Conflict of interest: None declared

Ethical approval: The study was approved by the Institutional Ethics Committee 


\section{REFERENCES}

1. Muir DG, Belsey MA. Pelvic inflammatory disease and its consequences in the developing world. Am J Obstet Gynecol. 1980;138:913-28.

2. Schaefer G. Female genital tuberculosis. Clin Obstet Gynecol. 1976;19:223-39.

3. Aka N, Vural TZE. Evaluation of patients of active pulmonary tuberculosis for genital involvement. J Obstet Gynecol Res. 1997;23:337-40.

4. Varma TR. Genital tuberculosis and subsequent fertility. Int J Gynecol Obstet. 1991;35:1-11.

5. Novak and Woodruff. Novak's gynecological and obstetrical pathology, $6^{\text {th }}$ Edition; 2007:1988.

6. Arora R, Rathore A. Female genital tract tuberculosis. In: Arora VK, Arora R.(eds) Practical Approach to Tuberculosis Management, $1^{\text {st }}$ edition. Delhi: Jaypee; 2006:113-119.

7. Bose M. Female genital tract tuberculosis: How long will it elude diagnosis? Indian J Med Res. 2011;134(1):13-4.

8. Bazaz Malik G, Maheshwari B, Lal N. Tuberculous endometritis: a clinicopathological study of 1000 cases. Br J Obstet Gynecol. 1983;90:84.

9. Bhanu NV, Singh UB, Chakraborty M. Improved diagnostic value of PCR in diagnosis of female genital tuberculosis leading to infertility. J Med Microbiol. 2005;54:927-31.

10. Jassawalla MJ. Genital tuberculosis: a diagnostic dilemma. J Obstet Gynecol India. 2006;56:203-4.

11. Jindal UN. An algorithmic approach to female genital tuberculosis causing infertility. Int $\mathrm{J}$ Tuber Lung Dis. 2006;10:1045-50.
12. Arora R, Rajaram P, Oumachigui A, Arora VK. Prospective analysis of short course chemotherapy in female genital tuberculosis. Int J Obstet Gynecol. 1992;38:311-4.

13. Rozati R, Roopa S, Rajeshwari CN. Evaluation of women with infertility and genital tuberculosis. J Obstet Gynecol India. 2006;56:423-6.

14. Gupta N, Sharma JB, Mittal s, Singh S, Mishra R, Kukreja M. Genital tuberculosis in infertility patients. Int J Gynecol Obstet. 2007;97:135-8.

15. Kulshrestha V, Kriplani A, Agarwal N, Singh UB, Rana T. Genital tuberculosis among infertile women and fertility outcome after antitubercular therapy. Int J Gynecol Obstet. 2011;113(3):229-34.

16. Schaefer G. Female genital tuberculosis. Clin Obstet Gynecol. 1976;19:223-39.

17. Bapna N, Mohanlal S, Namita K. Genital tuberculosis and its consequences on subsequent fertility. J Obstet Gynecol India. 2005;55(6):534-7.

18. Sin SY. Female genital tuberculosis. An update. Hong Kong Practioner. 1995;17(1):18-25.

19. Tripathy SN. Infertility and pregnancy outcome in female genital tuberculosis. Int J Gynaecol Obstet. 2002;76:159-63.

20. Puri S, Bhavana B. Diagnostic value of PCR in female genital TB and its therapeutic implications. J Obstet Gynecol India. 2009;59(1):67-70.

Cite this article as: Kamal S, Singh V, Singh S. A clinical study of association of genital tuberculosis with infertility in a tertiary centre of Jharkhand, India. Int J Reprod Contracept Obstet Gynecol 2020;9:120-5. 